Edited by

\title{
DEREK FRASER
}

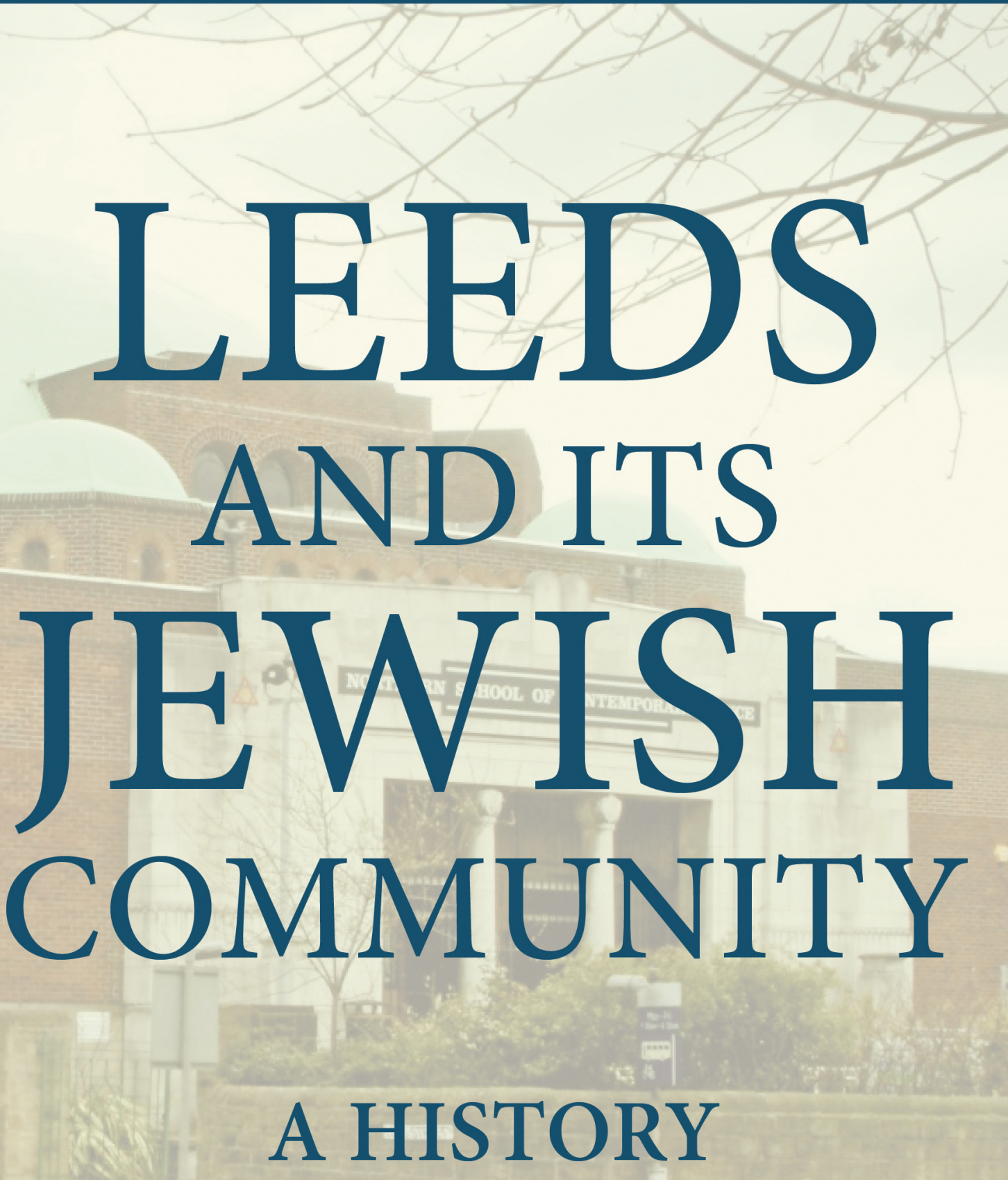




\section{Leeds and its Jewish community}

\section{MANCHESTER 1824}

Manchester University Press 
Derek Fraser - 9781526123091 


\title{
Leeds and its Jewish community
}

\author{
A history
}

Edited by

DEREK FRASER

Manchester University Press 
Copyright $\odot$ Manchester University Press 2019

While copyright in the volume as a whole is vested in Manchester University Press, copyright in individual chapters belongs to their respective authors, and no chapter may be reproduced wholly or in part without the express permission in writing of both author and publisher.

Published by Manchester University Press

Altrincham Street, Manchester M1 7JA

www.manchesteruniversitypress.co.uk

British Library Cataloguing-in-Publication Data

A catalogue record for this book is available from the British Library

ISBN 9781526123084 hardback

ISBN 9781526123107 paperback

First published 2019

The publisher has no responsibility for the persistence or accuracy of URLs for any external or thirdparty internet websites referred to in this book, and does not guarantee that any content on such websites is, or will remain, accurate or appropriate.

Typeset by

Servis Filmsetting Ltd, Stockport, Cheshire 